\title{
WATSON'S THEORY OF HUMAN CARING AND SUBJECTIVE LIVING EXPERIENCES: CARATIVE FACTORS/CARITAS PROCESSES AS A DISCIPLINARY GUIDE TO THE PROFESSIONAL NURSING PRACTICE ${ }^{1}$ A TEORIA DO CUIDADO HUMANO DE WATSON E AS EXPERIÊNCIAS SUBJETIVAS DE VIDA: FATORES CARITATIVOS/CARITAS PROCESSES COMO UM GUIA DISCIPLINAR PARA A PRÁTICA PROFISSIONAL DE ENFERMAGEM \\ LA TEORÍA DEL CUIDADO HUMANO DE WATSON Y LAS EXPERIENCIAS SUBJETIVAS DE VIDA: FACTORES CARITATIVOS/CARITAS PROCESSES COMO UNA GUÍA DISCIPLINAR PARA LA PRÁCTICA PROFESIONAL DE ENFERMERÍA
}

\author{
Jean Watson ${ }^{2}$
}

\footnotetext{
${ }^{1}$ This manuscript drawsupon a previous publication with modifications: WatsonJ. Carativefactors, Caritas processes guide to professional nursing. Danish Clinical Nursing Journal. 2006; 20 (3): 21-7.

${ }^{2} \mathrm{PhD}, \mathrm{RN}, \mathrm{AHN}-\mathrm{BC}, \mathrm{FAAN}$. Distinguished Professor of Nursing Murchinson-Scoville Endowed Chair in Caring Science, in the University of Colorado Denver and Health Sciences Center, USA. Web: www.uchsc.edu/nursing/caring
}

KEYWORDS: Teoria de enfermagem. Prática profissional. Cuidados de enfermagem. Enfermagem.

PALAVRAS-CHAVE: Nursing theory. Professional practice. Nursing care. Nursing.

PALABRAS CLAVE: Teoria de enfermería. Práctica profesional. Atención de enfermería. Enfermería.
ABSTRACT: This article provides an overview of Watson's theory of Human Caring, the notion of Caritas and human phenomena. Special emphasis is placed upon the theoretical structure of human caring theory referred to as 10 Carative Factors/Caritas Processes and subjective living processes and experiences. These core conceptual aspects of the theory and human living processes are grounded within the philosophical and ethical foundation of the body of my caring theory work. Together they serve as a guide for professional practice, as well as a disciplinary blueprint for the Science of Care.

RESUMO: Este artigo fornece uma visão geral da teoria de Cuidado Humano de Watson, a noção de Caritas e o fenômeno humano. Uma ênfase especial é dada sobre os 10 Fatores Caritativos/Caritas Processes, os processos de viver humano e as experiências subjetivas de vida que fazem parte da estrutura da teoria. Estes aspectos centrais dos conceitos da teoria e processos de viver são desenvolvidos na fundamentação filosófica e ética do corpo da Teoria de Cuidado. Juntos, eles servem como um guia para a prática profissional, bem como, um esquema disciplinar para a Ciência do Cuidado.
RESUMEN: El presente artículo ofrece una visión general sobre la teoría del Cuidado Humano de Watson, la noción de Caritas y el fenómeno humano. En este estudio se da un énfasis especial a los diez factores Caritativos/Caritas Processes, a los procesos del vivir humano y a las experiencias subjetivas de vida, los cuales forman parte de la estructura de la teoría. Los aspectos centrales de los conceptos de la teoría y los procesos del vivir son desarrollados en el fundamento filosófico y ético del cuerpo de la teoría de Cuidado; todos esos aspectos juntos sirven como una guía para la práctica profesional, así como también un esquema disciplinar para la Ciencia del Cuidado.
Endereço: Jean Watson University of Colorado Denver and Health Sciences Center 80262 - Denver, Colorado, USA.

Email: Jean.watson@uchsc.edu
Artigo original: Reflexão teórica Recebido em: 15 de agosto de 2006. Aprovação final: 23 de fevereiro de 2007. 


\section{INTRODUCTION}

The origin of the original theory of human caring was my first book - Nursing: the philosophy and science of caring. ${ }^{1}$ This first work was published before there was formal attention to nursing theory as the disciplinary foundation for nursing science, education, and practice.

The origin of the theory of human caring was first work "emerged from my quest to bring new meaning and dignity to the world of nursing and patient care" and to the inner subjective life experiences of self and other. ${ }^{2: 49}$ It also served to provide an ethicalphilosophical foundation for the deeply human dimensions of nursing.

The theoretical concepts were derived and emerged from, my personal/professional experiences; they were clinically inducted, empirically grounded and combined with my philosophical, intellectual, and experiential background. Thus, the early work emerged from my own values, beliefs, perceptions and experiences about rhetorical and ineffable questions, e.g. what does it mean to be human? What does it mean to care? What does it mean to heal? What does it mean to develop knowledge and practices about life phenomena and subjective human experiences? What is a living philosophical context for exploring nursing and life meaning in health and illness?

Questions and views of personhood, life, death, change, health, healing, caring, wholeness, pain, suffering, and so on, were guiding my quest to identify a framework for nursing as a distinct entity, profession, discipline and science in its own right, separate from, but complementary to medicine. ${ }^{1}$ My views were heightened by my commitment to the professional role and mission of nursing; its ethical covenant with society as sustaining human caring; in honoring the lived experience of self and other; in seeking to preserve humanity,even when threatened; attendingto and helping to sustain human dignity, unity of oneness of being, to hold the other in their wholeness, even when they could not feel whole themselves. These are all activities which transcend illness, diagnosis, condition, setting, and so on, and are enduring and timeless across time and space and changes in society and science.

Since then, the original work has expanded and evolved through a generation of other theory-based books on caring that followed:

- "Nursing: human science and human care, a theoryofnursing".Connecticut(USA):Appleton/Century/ Crofts.Reprinted/republished,New York(NY/USA):
National League for Nursing; 1988. Reprinted/republished, Massachusetts (USA): Jones \& Bartlett; $1999 .{ }^{3}$

- "Postmodern sursing and seyond". Edinburgh (Scotland): Churchill-Livingstone. Reprinted/republished, Harcourt-Brace/Elsevier; 1999. ${ }^{4}$

- "Caring science as sacred science". Philadelphia (USA): FA Davis; $2005 .{ }^{5}$

The first book "Nursing: the philosophy and science of caring" ${ }^{1}$ provided the original core and structurefor the Theory of Human Caring: 10 Carative Factors. These factors were identified as the essential aspects of caring in nursing, without which perhaps nurses were not practicing professional nursing, but were functioning as technicians or skilled workers within the dominant framework of medical technocure science. The second book "Nursing: human science and human care, a theory of nursing" ${ }^{3}$ expanded upon the philosophical, transpersonal aspects of a caringmoment asthecoreframework; thisfocus placed the ideas more explicitly within a broader context of ethics, art and even metaphysics-spiritual, as deeper living phenomena within which nursing dwells, but often does not name, nor articulate, nor act on.

As it has been pointed out in postmodern discourse today; "if a profession does not have its own language it does not exist", thus it is important to name, claim, articulate and act upon the phenomena of nursing and caring and the subjectively real living experiences of self and other; this focus for nursing and caring science is essential if nursing is to fulfill its mandate and raison d'êtreforexistinginscienceandsociety. Thisworkmakes more explicit that if nursing is to survive into this millennium then it has to sustain and make explicit its covenant with the public which includes knowledge, values, ethics and skilled practices of caring, healing, health, and living phenomena of human experiences.

Thethirdbook "Postmodernnursingandbeyond" brought a focus to the professional paradigm which is groundedin ontology of relations and an ethical-ontological foundation before the conventional epistemology of scienceandtechnology. Theneed toclarify theontological foundation of Being-in-Relation within a Caring paradigm; the unity of mindbodyspirit/field was the focus of this work, going beyond the outdated separatist ontology of modern, Era I medical industrial thinking.

It is here in this book that the spiritual and evolved energetic aspects of caring consciousness and intentionality and human presence and personal evolution of the practitioner became more developed. This evolution was placed within the emerging post -modern 
cosmology of healing, wholeness, oneness which is an honoring of the unity of all, and the living experiences and life phenomena in which nursing dwells.

My most recent theoretical book "Caring science as sacred science" 5 was selected as an AJN Book of the Year Award (2006) in the category of research; it expands further upon the original work on caring, now placing Caring Science within an ethical-moralphilosophical - evolved scientific context, guided by the works of Emmanual Levinas (French) ${ }^{6}$ and Knud Logstrup (Danish). ${ }^{7}$ This latest work seeks a science model that reintegrates metaphysics with the physical domain, and re-invites Ethics-of -Belonging, (to infinite field of Universal Cosmic Love) as before and underneath Being-by-Itself alone; this view is different, and separate from, the broader universal field of infinity, to which we all belong and return to from earth plane. This latest work brings a decidedly sacred dimension to the work of caring, making more explicit that living human experiences are a phenomena with spiritual and philosophical-ethical-moral dimensions; reminding us that we dwell in mystery. We dwell in mystery because we are working with the living processes, the life force, life energy, the soul if you will of another person.

This focus makes more explicit that relational, existential-spiritual human caring dimensions and the deeply life processes, the deeper meaning of life are part of the inner healing journey we make with self and others on this earth plane passage; this happens when we are practicing within a caring-healing model. When we are conscious of an expanded cosmology and expanded deeper moral-ethical foundation as the nature of caring and human living processes, we have to arrive at a new understanding and humility. We are asked to acknowledge a need for wisdom, even to surrender, to that which is greater than Self, and the outer world controls, that often we think we have.

With that background of my major books on Caring theory, Philosophy, and Caring Science the rest of this paper will explicate several of the conceptual aspects of the work; the core of the original work in context of its evolution; outlining the 10 Carative Factors (CF).

\section{DEVELOPMENT}

The Caritas Processes (CP) are juxtaposed against the original Carative Factors. The Caritas Processes are an extension of the other which have evolved; CP are intended to offer a more fluid language for understanding a deeper level of $\mathrm{CF}$ which capture the deeper dimensions of living processes of human experiences. The original terms and concepts of the Carative Factors needed to evolve as they seemed too set in the language of the earlier era, although still relevant.

Nevertheless, in this article, I am using the two forms almost interchangeable. However, Caritas makes more explicit the connection between Caring and Love and human living processes. These aspects are more prominent in my last book on caring science. ${ }^{5}$

Some exemplars of how the work in used as a guide to transforming practices within the context of living processes are included in Box 1.

Box 1 - 10 Carative factors and caritas processes.

\begin{tabular}{|l|l|}
\hline $\begin{array}{l}\text { Original 10 Carative Factors, juxtaposed } \\
\text { against the emerging Caritas Processes/ } \\
\text { Carative Factors }\end{array}$ & Caritas Processes \\
\hline 1. Humanistic -Altruistic Values. & 1. Practicing Loving-kindness \& Equanimity for self and other. \\
\hline 2. Instilling/enabling Faith \& Hope. & $\begin{array}{l}\text { 2. Being authentically present to/enabling/sustaining/honoring } \\
\text { deep belief system and subjective world of self/other. }\end{array}$ \\
\hline 3. Cultivation of Sensitivity to one's self and other. & $\begin{array}{l}\text { 3. Cultivating of one's own spiritual practices; deepening self- } \\
\text { awareness, going beyond "ego self". }\end{array}$ \\
\hline $\begin{array}{l}\text { 4. Development of helping-trusting, human } \\
\text { caring relationship. }\end{array}$ & $\begin{array}{l}\text { 4. Developing and sustaining a helping-trusting, authentic } \\
\text { caring relationship. }\end{array}$ \\
\hline $\begin{array}{l}\text { 5. Promotion and acceptance of expression of } \\
\text { positive and negative feelings. }\end{array}$ & $\begin{array}{l}\text { 5. Being present to, and supportive of, the expression of } \\
\text { positive and negative feelings as a connection with deeper } \\
\text { spirit of self and the one-being-cared-for. }\end{array}$ \\
\hline $\begin{array}{l}\text { 6. Systematic use of scientific (creative) problem- } \\
\text { solving caring process. }\end{array}$ & $\begin{array}{l}\text { 6. Creatively using presence of self and all ways of knowing/ } \\
\text { multiple ways of Being/doing as part of the caring process; } \\
\text { engaging in artistry of caring-healing practices. }\end{array}$ \\
\hline
\end{tabular}


7. Promotion of transpersonal teaching-learning.

8. Provision for a supportive, protective, and/or corrective mental, social, spiritual environment.

9. Assistance with gratification of human needs.

10. Allowance for existential-phenomenological spiritual dimensions.
7. Engaging in genuine teaching-learning experiences that attend to whole person, their meaning; attempting to stay within other's frame of reference.

8. Creating healing environment at all levels (physical, nonphysical, subtle environment of energy and consciousness whereby wholeness, beauty, comfort, dignity and peace are potentiated.

9. Assisting with basic needs, with an intentional, caring consciousness of touching and working with embodied spirit of individual, honoring unity of Being; allowing for spiritual emergence.

10. Opening and attending to spiritual-mysterious, unknown existential dimensions of life-death; attending to soul care for self and one- being- cared- for.
These 10 original Carative Factors remain as the timeless structural core of the Theory, while allowing for their evolving and emergence into more fluid aspects of the model captured by the 10 Caritas Processes.

In introducing the original concepts of Carative Factors as core for a nursing philosophy and science, I was offering a theoretical counterpoint to notion of Curative so dominant in medical science. Thus, the Carative Factors helped to define a framework to hold the discipline and profession of nursing; they were informed by a deeper vision and ethical commitment to the human dimensions /living processes of caring in nursing; the art and human science context. I was seeking to address those aspects of professional nursing that transcended medical diagnosis, disease, setting, limited and changing knowledge and technology of specialized foci. What remains as core? 10 Carative Factors (embellished by philosophical-ethic and value of Caritas consciousness).

In moving from the concept of Carative, to Caritas I was making an overt evocation of love and caring to merge for an expanded paradigm to connect with the existential-spiritual dimensions and living processes of human experiences. Such a perspective ironically places nursing in its most mature paradigm, while reconnecting with heritage and foundation of Nightingale which is the spiritual living processes of our humanity.

With Caritas incorporated more explicitly into my work, it locates the theory within an ethical and ontological contact as starting point for considering not only its science, but its societal human caring mission. This direction makes a more formal connection between caring and healing and the evolved human consciousness of living subjective experiences and life phenomena. The background for this work is published on my website. See www. uchsc.edu/nursing/caring for more information. ${ }^{8}$

\section{CONTEXT FOR CARATIVE/CARITAS PROCESSES}

The Carative Factors/Caritas Processes are not complete without acknowledging the worldview and philosophical context which holds the concepts. For example: a cosmology of oneness of Being; phenomenal field which honors the subjective-intersubjective inner life world, transpersonal caring relationship, caring occasion and caring moment. These wider dimensions serve to remind that any nurse - patient encounter can be considered a caring occasion wherein a "caring moment" can be created and experienced, depending upon the consciousness, intentionality, and philosophical (theoretical) orientation which is guiding the nurse. ${ }^{2}$ A caring moment transcends time and space and continues as part of larger complex pattern of life of both nurse and patient.

\section{Narrative related to Ten Carative Factors ${ }^{1}$}

\section{Humanistic: altruistic system of values}

Caring is grounded on a set of universal humanistic altruistic values. Humanistic values include kindness, empathy, concern, and love for self and others. They derive from childhood experiences and are enhanced by beliefs, cultures and art. Altruistic values arise from commitments to and satisfaction from receiving through giving. They bring meaning to one's life through one's belief and relationships with other people. Humanistic-altruistic feelings and acts provide the basis of human 
caring and promote the best professional care, and as such, constitute the first and most basic factor for science and ethic of caring.

\section{Enabling and sustaining faith and bope}

The history of medicine is replete with documentation of the importance of a person's belief in faith and hope. For example, Hippocrates thought that an ill person's mind and soul should be inspired before one's illness was treated. IN many other examples, medicine itself was secondary to magic, incantations, spells, and prayers. In this Carative Factor, patient's beliefs are encouraged, honored and respected as significant influences in promoting and maintaining health. Regardless of what scientific regimen is required for medical care of a person, the nurse should nurture faith and hope and the deep belief system of the one-being- cared for. Even when there is nothing left to do medically, the nurse nurtures a patient's faith and hope in something or someone beyond his or her self.

\section{Sensitivity to self and other}

To be human is to feel. All too often people allow themselves to think their thoughts, but not feel their feelings. The only way to develop sensitivity to one's self and to others is to recognize and feel one's feelings.

The development of self and the nurturing of judgment, taste, values, and sensitivity in human relationships evolve from emotional states. The development of feeling is encouraged by the humanities and compassionate life experiences.

Sensitivity to self is the recognition and acknowledgement of feelings - painful as well as happy ones. It is cultivated by looking into oneself and a willingness to explore one's own feelings. People who are not sensitive to and repress their own feelings may be unable to allow others to express and explore their feelings. Sensitivity to self not only leads to self-acceptance and psychological growth, but to sensitivity and acceptance of others.

Nurses who are sensitive to others are better able to learn about another's view of the world which, subsequently, increases concern for others' comfort, recovery, and wellness. Nurses who recognize and use their sensitivity promote selfdevelopment and self-actualization, and are able to encourage the same growth in others. Without this factor nursing care would fall.
Developing helping: trusting, caring relationship

The human caring relationship is transpersonal. in that it connotes a special kind of relationship: a connection with the other person, a high regard for the whole person and their Being-in-the-world. In the transpersonal human caring relationship, the nurse enters into the experience of another person, and another can enter into the nurse's experiences. It is an ideal of intersubjectivity in which both persons are involved. It is an art in which the nurse forms a union with the other, connecting with the spirit-filled person, behind the patient, that transcends the physical. This connection honors the upmost concern for human dignity and preservation of humanity.

\section{Promoting and accepting the expression of positive and negative feelings and emotions}

Because feelings after thoughts, behavior, and experiences, they need to need to be acknowledged and considered in the human caring process. A focus on feelings and the "non-rational" emotional aspects of an event is necessary for nurses engaged in the human caring process. The caring relationship can move to a deeper, more honest and authentic level if he nurse allows for this CF. Further, in listening to and honoring another person's feelings we honor their story which holds meaning and importance for them and their healing. By listening to another person's story, it may be the greatest healing act we can offer. It may be the nurse who is the only one who listens to and honors another's story and all the magnitude of feelings that accompany it.

\section{Engaging in creative, individualized, problem- solving caring process}

Professional nursing employs the nursing process, which is a creative, problem-solving method to assist with decision -making in all nursing situations. A creative approach acknowledges that nurses use all ways of know/being/doing in engaging in clinical caring. Nursing problems solving in not a linear one to one process, but often the nurse walks into a patient's room and grasps the "gestalt' - reading the field, in the instant. This process involves full use of self and all of one's faculties, knowledge, instincts, intuition, aesthetics, technology, skills, empirics, ethics, personal and even spiritual knowing. In a caring science model for practice, all knowledge is valu- 
able and accessed for clinical caring. The process invites creative imagination as well as systematic scientific logic and technology.

\section{Transpersonal Teaching-Learning}

Nurses have a long history about the educational-teaching role; however there has been more emphasis on conveying information rather than a conscious intentionality to engage in authentic processes and relationships of mutuality and reciprocity, in that the nurse seeks to work from the patient's frame of reference, grasping the meaning and significance of the information for the person, as well as the readiness and timeliness for the person to receive the information. This CF makes explicit that learning is more than just receiving information and data. It involves a caring relationship as context for any teaching learning. This CF evolves toward more of a coaching role in which the person becomes their own best teacher, in contrast to a conventional imparting- of- information role.

Provision of supportive, protective, and/or corrective mental, physical, societal, and spiritual environment

The purpose of providing such an environment is quality care and also healing/wholeness. The areas that involve this factor are: comfort; privacy; safety; clean; aesthetic surroundings.

Nurses often have a great deal of control of the environment, but without a consciousness of their obligations to take systematical responsibility for the environment to protect, support and/or correct the patient.

More recently this factor has taken on entirely new meaning. In addition to acknowledging the environment as a functional, physical place to attend to in conventional way, one now is invited to consider the nurse as influencing the patterns - for example, using theory as guide to environment one can think of the nurse as repatterning the environment to promote healing, harmony, and use of caring-healing modalities to assist in patterning a more healing environment; e.g. imagery, visualization, relaxation, music-sound, intentional touch, art and so forth. ${ }^{9,5}$ An even more expanded view of environment developed by Quinn ${ }^{9}$ and expanded by Watson ${ }^{5}$ suggests and invites us to consider the nurse as the environment. In this evolved framework we are invited to consider the practitioner and his/her evolved caring consciousness, presence, intentionality, and so forth, as the critical ingredient in the environment. ${ }^{5}$

In this view, then we have to turn toward the practitioner and the Nurse Self as an energetic, vibrational field, integral with the patient and outer environment. This is a unitary, caring science view of environment and raises new questions inspired by Quinn, ${ }^{9}$ for Caring Science Environment. ${ }^{5: 94}$

- If I am the environment, how can I Be a more caring-healing environment?

- How can I Become a safe space, a sacred vessel for this patient and his/her inner healing journey?

- In what ways can I look at, into this person (how am I to face this other) to draw out healing/ wholeness?

- How can I use my consciousness, my Being, my presence, my voice, my touch, my face, my hands, my heart for healing?

Environment now takes on entirely different meaning with this evolved view, moving beyond physical environment, and having to pay attention to the nurse and his/her caring consciousness affecting the entire field.

\section{Assisting with gratification of Basic Human Needs, while preserving buman dignity and wholeness}

Assistance with another's basic needs gives nurses access to the physical body in a very intimate way. As such it is a privilege and great gift to society to take care of others when in need of care. In a Caring Science model it is acknowledged that the nurse however is not just touching one' physical body or meeting physical needs, but noting that when touching another we are not touching just the body, but embodied spirit. It is also made explicit in this work that all needs are unified and interdependent; all needs are equally important and must be valued and responded to for caring-healing.

\section{Allowing for, being open to, existential-phenom- enological and spiritual dimensions of caring and bealing}

This last CF brings up the phenomenon of the unknowns, which cannot be explained scientifically, through the Western mind of modern medicine. This CF allows for mystery and philosophical, 
metaphysical aspects of human experiences and phenomena which do not conform to conventional views of science and rational thinking. Nevertheless these unknowns are real to those affected. This CF allows for spiritual filled meanings and unknowns to emerge open to infinite possibilities for miracles. This CF honors spirit- filled meanings, cultural beliefs, myths, and metaphors and inner subjective life world of nurse and patients and families, allowing cures and miraculous cures and healings.

\section{CONCLUSION}

Finally this framework for Caring Science and practices proposes that nursing, individually and collectively, contributes to the preservation of humanity and seeks to sustain caring in instances where it is threatened. The Carative Factors/ Caritas Processes serve as structure and order for a theoretical - philosophical foundation for the discipline and profession of nursing. The moral ideals and caring factors and processes proposed foster the evolution and deepening of humankind and serve to sustain humanity.

\section{REFERENCES}

1 Watson J. Nursing: the philosophy and science of caring. Boston (USA): Little Brown; 1979. Boulder (Colorado/USA): Colorado Associated University Press; reprinted 1985.

2 Watson J, The theory of human caring: retrospective and prospective. Nursing Science Quarterly. 1997 Mar; 10 (1): 49-52.

3 Watson J. Nursing human science and human care: a theory of nursing. Connecticut (USA): AppletonCentury Crofts; 1985. New York (USA): National League for Nursing; reprinted 1988. Massachusetts (USA): Jones and Bartlett; reprinted 1999.

4 Watson J. Postmodern nursing and beyond. Edinburgh (Scotland):Churchill-Livingstone.New York(NY/USA): Harcourt-Brace/Elsevier; reprinted 1999.

5 Watson J. Caring science as sacred science. Philadelphia (USA): FA Davis; 2005.

6 LevinasE. Totality \& infinity.Pittsburgh(PA):Duquesne University; 1969.

7 Logstrup K. The ethical demand. Notre Dame (Indiana/ USA): University of Notre Dame; 1997.

8 Watson J. Theory of human caring [acesso em $2006 \mathrm{Nov}$ 11].Disponívelem:http://www.uchsc.edu/nursing/caring

9 Quinn J. Holding sacred space: the nurse as healing environment.HolisticNursingPractice1992Apr;6(4):26-35. 